\title{
IMPACT OF INNOVATIONS ON THE PRODUCT MARKET COMPETITIVE DEVELOPMENT
}

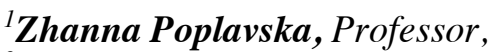 \\ ${ }^{2}$ Natalia Mykhalchyshyn, Associate Professor, \\ ${ }^{3}$ Oksana Goshovska, Associate Professor \\ Ukraine, Lviv, Lviv Polytechnic National University, \\ ${ }^{1}$ Head of Department of Theoretical and Applied Economics; \\ ${ }^{2}$ Department of Theoretical and Applied Economics; \\ ${ }^{3}$ Department of Theoretical and Applied Economics
}

DOI: https://doi.org/10.31435/rsglobal_ijite/30082018/6108

\begin{tabular}{l} 
ARTICLE INFO \\
Received 18 June 2018 \\
Accepted 14 August 2018 \\
Published 30 August 2018 \\
\hline KEYWORDS \\
competition, \\
competitive development, \\
competitiveness, \\
innovations, \\
innovativeness, \\
product market, \\
entry barriers
\end{tabular}

\begin{abstract}
Competitive product markets are characterized by aiming at complete consumers' needs satisfaction, flexible market price making, freedom of economic activity and entrepreneurship, free entry and exit from a market, fair trading and business practices etc. The highest values for the companies functioning at the competitive markets are consumers and consumer needs. Accordingly, all the decisions related to the companies' activity are being taken not based on the entrepreneurs' ambitions, but from the perspective of the consumer as the agent of future income and profits. One of the essential characteristics of the markets competitive development is ability of the market players to optimize costs, minimize prices, and improve product quality for the maximum consumer satisfaction. Innovations are one of the means for providing competitive development path. However, the essence of innovations is not only introducing something new, some quality changes of the entrepreneurship activity. This economic category may manifest itself as a barrier for entry into product markets, and may cause emerging of innovative monopolies that eventually influence competitive development. Presented article is dedicated to the outcomes of innovative activity on the marketplace. Interconnections between the competitive environment and innovativeness are being investigated, and as the result, innovativeness is proven a method of overcoming competitive pressure, achieving competitive advantages at the market. It is determined that innovativeness depends on the companies' size, as the financial capacity for innovations and availability of the labour potential concentrated in the innovative area are higher within big companies. As well the need for innovativeness as the mean for attaining competitive advantages depends both on the industry type and the product market characteristics, where a company is functioning, as there are no needs for competitive advantages at monopolistic markets. Innovations may also appear in natural monopolies as the result of introducing some regulatory policies. Also the causality between companies' pursuance of uniqueness, the level of national competitiveness - and the innovations is being investigated, as well as the time lag between introduction of innovations and gaining some competitive advantages at the market. Understanding mutual influences of innovations and product markets competitive development is the clue for taking proper decisions by regulatory bodies with respect to markets development. Appearance of innovative monopolies aggravate the demand for regulatory bodies control over product markets development with the purpose of preventing excessive use of the market power by innovative monopolies.
\end{abstract}

Citation: Zhanna Poplavska, Natalia Mykhalchyshyn, Oksana Goshovska. (2018) Impact of Innovations on the Product Market Competitive Development International Journal of Innovative Technologies in Economy. 7(19). doi: 10.31435/rsglobal_ijite/30082018/6108

Copyright: (C) 2018 Zhanna Poplavska, Natalia Mykhalchyshyn, Oksana Goshovska. This is an open-access article distributed under the terms of the Creative Commons Attribution License (CC BY). The use, distribution or reproduction in other forums is permitted, provided the original author(s) or licensor are credited and that the original publication in this journal is cited, in accordance with accepted academic practice. No use, distribution or reproduction is permitted which does not comply with these terms. 
Introduction. Product markets within any economic system emerge and form under the influence of the market players - namely their actions in the framework of competition for customers and profits. Product market competition arises as firms endeavour to establish an advantageous position over other businesses trying to maintain and increase their market share. Competitive mechanism is a complex process with the extent and type of competition changing over time as firms enter and leave the market, as new products and processes are introduced, and as firms employ different competitive strategies.

Ability of a certain company to interact actively at the market depends both on internal and external factors. External factors encounter first of all consumer tastes, market saturation, number of market players etc. Thus, changes in consumer tastes compel the companies to reorient, master new production technologies, in some particular cases - differentiate the types of activity, suggested products and services. For avoiding fierce competition in case of high market saturation, some companies initiate innovative activity in order to gain an edge in the competition for global tradeIn such cases, innovations become the instrument for competitive development.

In particular cases, at the markets with high innovation activity, the innovations may turn into entry barriers. Companies failing to overcome the innovation barriers, even given high internal potential, will not be able to get into the market. Correspondingly, only few companies will be able to function at the market, which may result in their misuse of the market power and harm the markets competitive development.

Literature review. Product markets development is subject of investigation by many scientists. In particular, the market environment is being investigated, losses and gains for enterprises entering and leaving the markets. Innovations are considered as the mean of companies' differentiation at the market, or in contrary - create uncontested market niche by overstepping market boundaries. Thus, according to the Blue Ocean strategy (Kim W.Chan and Renee Mauborgne, 2016) innovations are the mean of reaching beyond existing demand and supply in new market spaces. According to Schumpeter's Theory of Economic Development (J.Schumpeter, 1995), creating innovation is the result of competition at product markets. Competition influence on the innovative development and economic's competitiveness was investigated by such local scientists as V.Lagutin and Yu.Lasko concluding that economic competition causes innovative development (V.Lagutin, Yu.Lasko, 2013). This thesis relates to the Blue Ocean strategy, as far as innovative activity emerges due to the urge to differentiate from existing competitors. However, taking into account the theory of innovative monopoly and pursuance of enterprises to avoid competitive pressure through innovations, it can be expected that product markets may attain certain level of development and then transform from competitive to monopolistic, what as the result will stem competition development.

According to scientific research by a group of authors under the guidance of Bila S.O. (Bila S.O. and others, 2011), one of the features of innovativeness is presence of clusters; low level of clusters development in Ukraine is caused by "low level of competition at the internal market, absence of "aggressive" suppliers and demanding consumers" (Bila S.O. and others, 2011). Hence it follows that innovativeness is evoking both from competitors' activity at the markets and influence of other market factors, such as market power of consumers and suppliers. Taking into account that innovations, competition, consumers and suppliers, and competitiveness are in close interrelations, one of the tasks defined in this scientific research is to find out what exactly are the factors of innovation influence on competitive development.

Research methods. In the field of investigating innovations in the context of competitive development of product markets the methods of analysis and synthesis for existent theoretical and practical approaches to the concept of "innovative activity", conditions for maintaining enterprises' innovativeness, negative consequences of innovative activity, as well as obligations of innovators for retaining their market positions at certain product markets.

The method of comparative analysis has also been applied to the results of assessing innovative activity in the Ukrainian economy during 2014-2016 (in compliance with generally accepted statistical methodology) in accordance with the official statistic data of Ukraine. The study has been performed taking into account expert estimation of risks in different sectors of economy by GfK Ukraine, as well as the polling of companies' managers, conducted by the Antimonopoly committee of Ukraine and the Center of complex studies on antimonopoly issues in 2016. The interrelation between innovations and competitiveness has been defined based on the World Intellectual property organization about Global Innovation Index 2017 and Insight Report of World Economic Forum about Global Competitiveness Rank. 
Analysis/study/results. Possessing financial assets is not a sufficient condition for implementing innovative activity at the companies. Quite often one of the obstacles for innovativeness is company inability to strategically estimate the prospects of market development, as well as evaluate its own possibilities of adaptation to such changes. A company's goal is to maximize profits in the long term, and in order to gain that, a company needs to constantly modernize and invest.

As is argued by practitioners, in order to develop innovative activity it is necessary to:

- be ready for the risks and to give up traditional approaches to market changes;

- realize versatility of consumers' needs and desires, as well as uncertainty of consumer wants;

- be able to analyze not only traditional business indexes but also strategic growth indexes;

- forecast changes in demand at the of innovative product market, and be able to satisfy such growing demand (Rebecca O. Bagley, 2013).

Hence, innovation may be seen as a mechanism of solving current and potential problems of supply, satisfying consumers' needs, and competitive interaction of goods at the market. Innovation, as new goods, services and technologies, are the means for companies to cope with the pressures of competitive markets and therefore one of interesting features of competition. A firm should be ready for certain expenses related to innovation, and temporarily drops in current profit for the sake of company success in the future.

Introducing innovation can help firm to: improve productivity, reduce costs, be more competitive, build the value of your brand, establish new partnerships and relationships, increase turnover and improve profitability. To be competitive in the modern environment, companies must orient quickly for creation of new products, technologies and qualification of the employees - activities related to promotion of innovation, which organizations provide primarily increasing the competitiveness of their products in contemporary conditions. Businesses that fail to innovate run the risk of: losing market share to competitors, falling productivity and efficiency, losing key staff, experiencing steadily reducing margins and profit, going out of business (GOV.UK/Busines, 2009).

Therefore, innovations are not only the instrument for gaining competitive advantages, but also the mean of achieving victory in the competitive struggle. Owing to innovations, companies gain market leadership and maximize their profits. However, market leadership in the conditions of fierce competition and threat of market entry by potential competitors, demands constant market monitoring and innovations implementing. As has been demonstrated globally by leading companies, such as company Avery - a global leader in labeling and packaging solutions, innovativeness should not be perceived as a single time measure, as the long-term success will depend on continuous innovation (Rebecca O. Bagley, 2013). Along with loosing ability for innovativeness and fierce competition from the side of highly innovative rivals, the companies are losing market leadership position and are under the risk of losing market position at all.

For the sake of supporting innovativeness level, the companies need to analyze possible sources of innovative ideas, and depending on the particular market conditions to define and introduce the priority ones. The sources for innovative ideas may be both internal - emerging within the business activity (e.g. from employees, managers or in-house research and development work), and external - those arising in the environment (e.g. suppliers, customers, media reports, market research published by another organization, or universities and other sources of new technologies) (GOV.UK/Business, 2009). Consequently, the internal sources are mostly related to the managerial decisions, ability to support workforce with high intellectual potential, capable of taking nonstandard decisions with innovative emphasis. Therefore, it is important to develop corporative and competitive environment within the company, where each particular employee is conscious of his/her role and significance in the company life, and all the company problems are perceived as personal, maximum efforts are invested for solving them.

Presence of external innovativeness resources and possibility of their exploiting depend on strong company interrelations with its consumers and suppliers, on the workers competence for collecting information about market changes and performing market analytics. They also depend on the degree of media development and their capacity for independent journalistic investigations of market trends, settling collaboration between science and business, etc.

Exploiting different sources for innovative ideas and the companies' urge for innovativeness and distinctiveness among the rivals may result in gaining a market share with innovative entry barriers. The companies approaching the problem of competitive interaction at the market are thus implementing the Blue Ocean strategy. For such companies making the competition irrelevant by creating blue oceans of uncontested marketplace. An example that shows that the creation of blue oceans can bring profit and growth is Ford and the Model T. In 1908 Ford came up with a new innovation, the Model T, and created the automobile industry 
as we know it today. This strategic move helped Ford's market share to rise from 9 to 61 percent (Kritiotis C., 2015).

Porter's five competitive forces include three forces from 'horizontal' competition--the threat of substitute products or services, the threat of established rivals, and the threat of new entrants--and two others from 'vertical' competition--the bargaining power of suppliers and the bargaining power of customers (Michael E. Porter, 2008, p.86). In case of capturing a new market niche via the Blue Ocean strategy the influence of horizontal competition is being levelled, while the vertical competition is getting more intense. Their own interests, as well as changes in consumers and suppliers needs lead the companies' activity.

At non-competitive markets, consumers may not have any alternatives for innovative goods, and as a result, there will be preconditions for market power abuse provided by the degree of consumer dependence on such innovative goods, in other words - low demand elasticity. Such abuse may appear through defining the terms of product sales and pricing with market mechanisms violation, refuse in access to the product purchase with the aim of artificial product shortage and future price increase. Such actions of enterprises are similar to monopolists' activity, when consumers are sometimes made worse off if a company uses its market power to set a higher price and provide a lower quantity of its product.

The main tasks of competition are the search for new ideas, developing new goods for more complete satisfaction of consumer needs, gaining highest income by firms that own the best competitive position. Among competition's important virtues are its ability to allocate resources in a free market and create the grounds for the customers' free opportunity to select among alternative offers. Competition can yield minimum costs for suppliers and lower prices for goods and services, their better quality, higher variety of choices, more innovation, higher production and market efficiency, and economic growth and development.

Competition can also influence productivity growth directly through the process of "creative destruction" - a term coined by Joseph Schumpeter (1995). In competitive markets, firms with relatively poorer productivity than their counterparts are more likely either to be forced to improve their productivity to retain their market share or lose market share and possibly be driven out of business. Following Joseph Schumpeter, one can state that monopoly and large scale promote investment in research and development by allowing a firm to capture a larger fraction of its benefits and by providing a more stable platform for a firm to invest in research and development. Schumpeter claimed that economics benefits from competition from the new commodity, new technology, the new source of supply, new type of organization. Schumpeter argued on this basis that some degree of monopoly is preferable to perfect competition. (J. Schumpeter, 1995). Should the company seize a market niche according to the Blue Ocean strategy, it may loose the ability to innovate and improve, thus the ground task of competition will not be accomplished in full. Holding the market positions under such conditions will be possible according to the Blue Ocean strategy given the unchangeable customer tastes, intense interrelations with the customers and persuading them in high value of a certain product. The companies implementing the Blue Ocean strategy may have no need for future innovations.

As Kim W.Chan and Renee Mauborgne (2016) argue the Blue Ocean Strategy aims to capture new demand, and to make competition irrelevant by introducing a product with superior features. It helps the company in making high profits as the product can be priced a little steep because of its unique features. It builds up powerful incentives not only for the initial cost savings, but also for constantly maintaining them on the same level and thus creating boundaries for the potential followers (Kim W.Chan and Renee Mauborgne (2016) p.p. 348-349). From the perspective of blue ocean strategy, companies seeking profitable growth should not focus their efforts on identifying an existing conventional market, but should set out to create innovative value and capture a market niche.

Whereas innovations give the companies an opportunity to gain differentiation and certain competitive edges at the market, serious efforts are demanded for gaining support of innovative ideas by the customers.

J. Schumpeter in his work «Capitalism, Socialism and Democracy» stated that it is always difficult to create anything new, and its implementation is a separate independent economic function, as novelty is normally out of boundaries for understandable tasks and meets resistence of environment - starting from the denial to finance innovative products, refusal to purchase the new good, and finishing with physical elimination of the innovator (J. Schumpeter, 1995). Hence innovativeness in a competitive environment can be interpreted both as a challenge for the innovator, for consumers and existent competitors at the market. As for the innovator, the companies should be ready to percept not 
only financially, but also psychologically an innovative idea and its implementation. As for the existing competitors at the market, in most cases companies that share a market are accustomed to the market environment, and they may perceive innovativeness foremost as a threat of loosing their consumers, that may be eager to switch to the innovative approach and will refuse of their products.

Therefore, opposing the market changes and the market shares redistribution, as well as relocation of profits, existing competitors may create obstacles for innovativeness and prevent the companies-innovators from leaving the conventional environment, as innovation may lead to bancrupcy the companies unable to innovate. Such a problem of non-acceptance may be avoided in case if the company-innovator offers fundamentally different idea and new value for consumers.

Interrelation of competition and innovation may be presented similarly to the correlation of competition and monopoly (Figure 1).

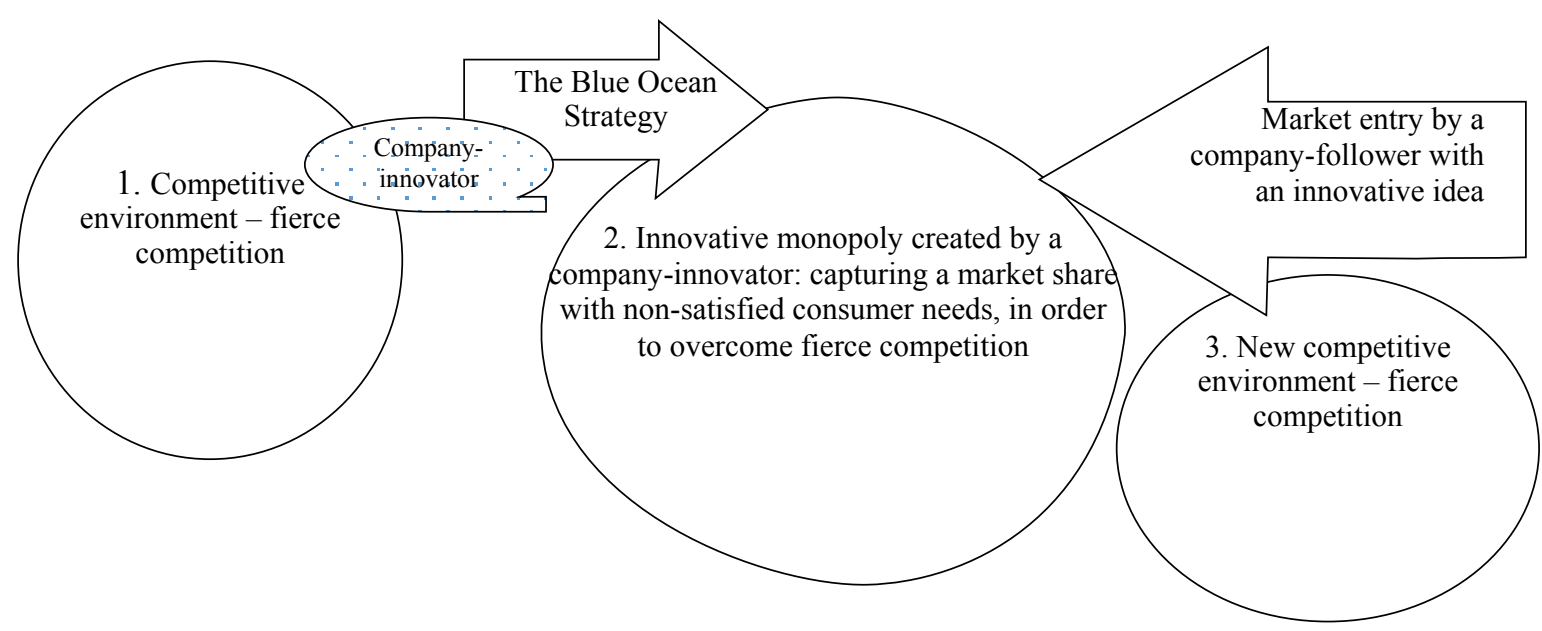

Fig.1. Correlation of competitive environment and innovation

Source: Poplavska Zh., Mykhalchyshyn N., Hoshovska O. (2018)

Thus, companies that function in competitive environment meet hursh competition and strive to avoid it, aim their efforts at innovativeness, and as a result - innovative monopolists that function outside the limits of competitive environment appear on certain market niches. On the other hand - an innovator may lose its exceptional market position in time, when the captured market niche will be targeted by another market player with yet better innovative technology. Under such conditions, no company can be sure of keeping the competitive status quo.

Sometimes the level of innovativeness depends on the company size. As known, on most real markets small and middle companies compete with each other; large enterprises are present mainly on the markets, where competition is comparatively weak. Broadly speaking about innovative activity, it should be more inherent therefore to small and middle enterprises, the number of which is far bigger than that of the big companies. However, i.e. in Ukraine, during 2014-2016 innovative activity was rather typical for big enterprises with the amount of employees over 250 (Prylupko R.Yu., 2017).

Innovative activity also differs substantially in the context of industries. As seen from the data in Table 1, innovative activity levels may be split into high (for industries like processing, information and telecommunication, financial and insurance activity), middle (for industries as extraction and mining, electric power supply, gas, pair and condensed air supply, wholesale, except trading of auto vehicles and motor cycles) and low (for industries - water-supply; sewage system, handling wastes, financial and insurance). 
Table 1. Innovation activity and competitive factors dynamics in Ukraine during 2014-2016 considering existing risks in certain fields of economics in 2015 (Prylypko R.Yu., 2017; GfK Ukraine, 2015; Antimonopoly Committee of Ukraine, 2017)

\begin{tabular}{|c|c|c|c|}
\hline $\begin{array}{l}\text { Type of economic } \\
\text { activity (KVED- } \\
\text { 2010)/economic field }\end{array}$ & $\begin{array}{l}\text { Companies' innovative } \\
\text { activity in } 2014-2016, \% \\
\text { share of the generally } \\
\text { studied companies within } \\
\text { the economic field }\end{array}$ & $\begin{array}{l}\text { Risks in inconomic } \\
\text { fields according to } \\
\text { the GfK Ukraine } \\
\text { expert estimation in } \\
2015\end{array}$ & $\begin{array}{l}\text { Share of the } \\
\text { respondents, } \\
\text { estimating the level } \\
\text { of competition in } \\
\text { Ukraine as high in } \\
\text { 2014-2016, \%1 }\end{array}$ \\
\hline Mining industry & 14,2 & $\begin{array}{l}\text { Cyclical and } \\
\text { structural risks }\end{array}$ & \multirow[t]{2}{*}{43} \\
\hline Processing industry & 21,9 & Low risk level & \\
\hline $\begin{array}{l}\text { Electricity, gas, steam } \\
\text { and condenced air } \\
\text { supply industry }\end{array}$ & 15,4 & Low risk level & $\begin{array}{lr}\text { No } & \text { competition, } \\
\text { natual } & \text { monopoly } \\
\text { features } & \\
\end{array}$ \\
\hline $\begin{array}{l}\text { Water supply; sewage, } \\
\text { waste utilization }\end{array}$ & 9,8 & Low risk level & $\begin{array}{lr}\text { No } & \text { competition, } \\
\text { natual } & \text { monopoly } \\
\text { features } & \\
\end{array}$ \\
\hline $\begin{array}{l}\text { Wholesale, except } \\
\text { sales of cars and } \\
\text { motobikes }\end{array}$ & 17,3 & Cyclical risks & $\begin{array}{l}\text { Data on wholesale } \\
\text { trade not available. } \\
\text { Index in trade is } \\
51,87\end{array}$ \\
\hline $\begin{array}{l}\text { Transportation, } \\
\text { wharehousing } \\
\text { business, postal and } \\
\text { courier services }\end{array}$ & 9,7 & Cyclical risks & 33,03 \\
\hline $\begin{array}{l}\text { Information and } \\
\text { telecommunication }\end{array}$ & 22,1 & Low risk level & \\
\hline $\begin{array}{l}\text { Financial and } \\
\text { insurance activity }\end{array}$ & 21,7 & Cyclical risks & 52,3 \\
\hline
\end{tabular}

The research data presented in Table 1, confirm ambiguous influence of economic risks on innovative activity, as quite low level of risks, and cyclic risks, are incidental to all levels of innovativeness. Moreover, a combination of cyclic and structural risk characteristically for the middle level of innovativeness. As for competition, high level of competition is common both for highly- and middleinnovative industries. Thus, high level of innovativeness can show up regardless of economic risks and level of competition, which may prove stronger dependence of innovativeness on companies' intentions to become exceptional at a certain market niche and their ability to attain such differentiation.

Competitiveness index is normally applied both to particular markets and countries in general. Just as companies compete for market share, capital and investors, nations compete for investments, trade in goods and services. The focus on national competitiveness has been increasingly reinforced by global competitiveness rankings published, by a variety of institutions. They measure and track nations across various metrics and indicators, including the strength of their public and private institutions, the quality of their infrastructure, their macroeconomic environment, education, health, market efficiency, financial market development, and their state of bureaucracy and transaction costs and flows, among others. In other words, international rankings paint a picture of a country's ability to attract investments, raise per capita GDP, create jobs and wealth for itself, and ultimately raise the standard of living for its own people.

Analyzing the Global Innovation Index for 2016-2017 rankings and the Global Competitiveness Rank, we can notice that Switzerland is the only country leading both in competitivenexx and innovations (Table 2).

\footnotetext{
${ }^{1}$ Arithmetic mean of the index over 2014-2016 calculated by the authors based on the available data (Antimonopoly Committee of Ukraine, 2017)
} 
Table 2. Global Innovation Index rankings and Global Competitiveness Rank (Cornell University, INSEAD Europe, WIPO, 2017, Schwab K., 2016, Schwab K., 2017)

\begin{tabular}{|l|c|c|c|c|}
\hline \multicolumn{1}{|c|}{ Country } & $\begin{array}{c}\text { Global } \\
\text { Competitiveness } \\
\text { Rank, 2016-2017 }\end{array}$ & $\begin{array}{c}\text { Global } \\
\text { Competitiveness } \\
\text { Rank, 2017-2018 }\end{array}$ & $\begin{array}{c}\text { The Global } \\
\text { Innovation } \\
\text { Index, 2016 }\end{array}$ & $\begin{array}{c}\text { The Global } \\
\text { Innovation } \\
\text { Index, 2017 }\end{array}$ \\
\hline Switzerland & 1 & 1 & 1 & 1 \\
\hline United states & 3 & 2 & 4 & 4 \\
\hline Singapore & 2 & 3 & 6 & 7 \\
\hline Netherlands & 4 & 4 & 9 & 3 \\
\hline Germany & 5 & 5 & 10 & 9 \\
\hline Hong Kong SAR & 9 & 6 & 14 & 16 \\
\hline Sweden & 6 & 7 & 2 & 2 \\
\hline United Kingdom & 7 & 8 & 3 & 5 \\
\hline Japan & 8 & 9 & 16 & 14 \\
\hline Finland & 10 & 10 & 5 & 8 \\
\hline
\end{tabular}

Alongside, the growth of competitiveness level in Singapore, Sweden, United Kingdom, Japan in 2017 has been accompanied by innovativeness growth, excluding Japan, where the level of innovativeness has dropped. Also stable competitiveness level may be followed by the increase in innovativeness, as in Finland, or its decrease - as in Germany and Netherlands. A conclusion may be drawn that among the 10 leading countries only $50 \%$ fit to the prior hypothesis that a direct relationship exists between innovativeness and competitiveness levels.

In relation to other countries the abovementioned hypothesis was not confirmed, so it is possible to draw a conclusion, that interrelations between innovativeness and competitiveness have national specific features that are related to economic development of each separate state. Thus, in case of Japan the decline of innovativeness level along with the increase of competitiveness level can testify the attainment of certain level of innovativeness a country, which provides the high level of competitiveness in future. In case of Germany and Netherlands a certain high level of competitiveness has been achieved, which is not further influenced by innovativeness. Most probably, the increase of innovative activity in a current period can provide increase of competitiveness level in the future.

Also, from a long-run perspective, it can be determined that the cost of improving competitiveness can exceed static gains observed in the short term, but also in the long term all the benefits that determine the economic sense of innovation are observed.

Therefore, the mutual influence of innovativeness and competitiveness depend on the national distinctive features of the economic systems, the time lag between innovations implementation and attaining competitive advantages, and competitive level as the result. Innovativeness of enterprises, regardless of market conditions, is in most cases characterized by both positive and negative consequences (Figure 2).

\begin{tabular}{|c|c|c|}
\hline \multicolumn{2}{|c|}{ Outcomes of companies' innovativeness at the product markets } & oduct markets \\
\hline $\begin{array}{l}\text { Positive: } \\
\text { - improving labour efficiency; } \\
\text { - cost saving; } \\
\text { - competitiveness increase; } \\
\text { - developing new market } \\
\text { relations; } \\
\text { - increasing indexes of current } \\
\text { ratio and profitability; } \\
\text { - company brand development; } \\
\text { - profit maximization; } \\
\text { - gaining market leadership. }\end{array}$ & $\begin{array}{l}\text { Negative: } \\
\text { - slowing-down of the } \\
\text { further innovation } \\
\text { development; } \\
\text { - deprivation of the } \\
\text { ability to improve by the } \\
\text { company-innovator; } \\
\text { - challenge of changes in } \\
\text { consumer values, } \\
\text { including the tastes } \\
\text { regarding innovative } \\
\text { products. }\end{array}$ & $\begin{array}{l}\text { Additional requirements to the } \\
\text { innovator: } \\
\text { - constant market monitoring; } \\
\text { - continuous innovative activity; } \\
\text { - search and analysis of the sources for } \\
\text { innovative ideas (both internal and } \\
\text { external); } \\
\text { - ability to build tight relations with } \\
\text { consumers and suppliers; } \\
\text { - analysis of the threats of entry by other } \\
\text { companies with better innovative idea into } \\
\text { the current market niche; } \\
\text { - necessity to maintain minimum possible }\end{array}$ \\
\hline
\end{tabular}

Fig. 2. Outcomes of companies' innovativeness at the product markets Source: Poplavska Zh., Mykhalchyshyn N., Hoshovska O. (2018) 
Should the positive outcomes of innovativeness prevail, competitive development of the markets will continue. Otherwise, an innovator may loose its market share, influenced by imitators or consumer value innovators.

Also unforecasted changes of consumer values, not expected by a company, may result in the loss of the company's market position attained due to its previous innovative steps. Feeling the threat of the market loss, companies may be engaged into uncompetitive actions, which will prevent market competition development.

Discussion. Competition development, innovations and competitiveness belong to such economic categories that can be estimated both on macro- and on microlevels. Analogical macroindexes are formed and dependent on the microindexes - in particular, such as innovativeness, competition development and competitiveness of individual market participants. However, taking into account existent methodology and statistical data in Ukraine, investigation of competitive development, degree of innovativeness within different types of economic activity becomes possible only through questioning of wide circle of respondents, which may become the subject of future studies.

Conclusions. Innnovations are considered the driving force of economic development within different economic systems, and accordingly most countries choose innovative development as the primary direction. If we compare J.Schumpeter's theory of competition (J.Schumpeter, 1995) with definition of innovation, we actually see that these two economic concepts are similar and are developing simultaneously - the task of competition may not be fulfilled without innovative approach. On the other hand, there are areas of economic activity with characteristics of natural monopoly, where companies avoid investments into innovativations, exploiting the features of demand and absence of substitutes for their products.

Therefore, innovativeness as an event may emerge autonomously only in competitive environment. In such conditions innovativeness is the mean of gaining competitive advantages and therefore creates benefits for competitive development, as actually most competitive companies get the highest share of profits and satisfy consumer needs at most. Besides, a company with highest innovative potential least likely enter into non-rival agreements. As proven by studies results, companies succeed in capturing market shares given constant and continuous dedication to innovations. However, cases where innovations become the spoiler of competitive development are common as well. It may be possible when a company has gained certain level of innovativeness, has defined and captured some market demand, and started to loose the ability to innovate. Should a rival with some better innovative idea decide to enter the same market, the existing market player will try to create barriers for entry. Thus features of non-rival development appear.

Considering the results of analyzing interrelations of competition and innovations, we have found out that the urge for differentiation influences the company innovative activity most. The link between risk tolerance and innovations is not very clear.

Thus, both positive and negative influence of innovations on the competitive development is possible. In case of negative influence companiesinnovators will try to keep the captured market share and will not be able to adapt to changes in consumer tastes, instead will try to create barriers for entry for potential rivals, and in turn the markets competitive development will be terminated.

\section{REFERENCES}

1. Almunia J. (2012) Competition policy for innovation and growth: Keeping markets open and efficient. Available in http://europa.eu/rapid/press-release_SPEECH-12-172_en.pdf.

2. Cornell University, INSEAD Europe, WIPO (2017). Global Innovation Index 2017: Switzerland, Sweden, Netherlands, USA, UK Top Annual Ranking. Available in http://www.wipo.int/pressroom/en/articles/2017/article_0006.html.

3. GfK Ukraine (2015). Експертна оцінка GfK Ukraine, розрахунки GfK Ukraine. Available in https://www.gfk.com/fileadmin/user_upload/dyna_content_import/2015-0901_news/data/ua/Documents/GfK\% $\overline{20}$ cities $\% 202015 \% 20$ sustainability\%20to\%20xternal\%20markets\%20 changes.pdf.

4. GOV.UK/Busines (2009). Use innovation to grow your business. Available in $\mathrm{http} / / / \mathrm{www}$.infoentrepreneurs.org/en/guides/use-innovation-to-grow-your-business.

5. Kim W.Chan and Renee Mauborgne (2016). Blue ocean strategy: how to create uncontested market space and make competition irrelevant/W.Chan Kim, Renee Mauborgne; переклад з англ. І.Андрущенка. Харків: Книжковий клуб «Клуб Сімейного Дозвілля», 2016. - 288 р.

6. Kritiotis C. (2015). The Role of Innovation in Firm Competitiveness. Available in https://themarketmogul.com/role-innovation-firm-competitiveness. 
7. Michael E. Porter (2008, p.86). «The Five Competitive Forces that Shape Strategy», Harvard Business Review, January, 2008, p.86.

8. Rebecca O. Bagley (2013). Innovate, Grow, Succeed: Staying Competitive in Today's Economy. Available in https://www.forbes.com/forbes/welcome/?toURL=https://www.forbes.com/sites/rebeccabagley/2013/03/18/in novate-grow-succeed/\&refURL=https://www.google.com.ua/\&referrer=https://www.google.com.ua.

9. Schwab K. (2017). The Global Competitiveness Report 2017-2018. World Economic Forum. Available in http://reports.weforum.org/pdf/gci-2017-2018-scorecard/WEF_GCI_2017_2018_Scorecard_GCI.pdf.

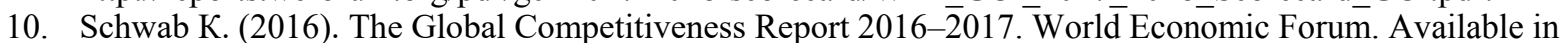
http://www3.weforum.org/docs/GCR2016-2017/05FullReport/TheGlobalCompetitivenessReport20162017 FINAL.pdf.

11. Антимонопольний комітет України (2017). Звіт АМКУ за 2016 р. Available in http://www.amc.gov.ua/amku/doccatalog/document?id=133712.

12. Біла С. О. та ін. (2011). Інноваційні підходи до регіонального розвитку в Україні / під кер. Біла С. О./ Жаліло Я. А., Жук В. І., Кушнір М. О., Лупацій В. С., Собкевич О. В. та ін. - К.: НІСД, 2011. - 47 с. Available in http://www.niss.gov.ua/content/articles/files/inovac_pidhod-d3220.pdf.

13. Лагутін В., Ясько Ю. (2013). Вплив конкуренції на інноваційний розвиток та конкурентоспроможність економіки/ В.Лагутін, Ю. Ясько// Економіка, 2013. - 10(151). Available in http://bulletin-econom.univ.kiev.ua/wp-content/uploads/2015/11/151_5.pdf.

14. Прилипко Р. Ю. (2017). Обстеження інноваційної діяльності в економіці України за період 2014-2016 років (за міжнародною методологією). Available in http://www.ukrstat.gov.ua/druk/publicat/kat_u/publnauka_u.htm.

15. Шумпетер Й. А. (1995). Капитализм, социализм и демократия. Available in http://uaterra.in.ua/wpcontent/uploads/2017/11/SHumpeter-Jozef.pdf 